\title{
COMPUTER ENGINEERING
}

UDC 621.396.551.553(045)

DOI:10.18372/1990-5548.66.15227

${ }^{1}$ V. M. Sineglazov,
${ }^{2}$ R. L. Pantyeyev,
${ }^{3}$ O. V. Balov

\section{AUTOMATIC SYSTEM FOR UAV IDENTIFICATION IN MULTI-POSITION SOUND MONITORING SYSTEMS}

\begin{abstract}
Aviation Computer-Integrated Systems Department, National Aviation University, Kyiv, Ukraine E-mails: ${ }^{1}$ svm@nau.edu.ua ORCID 0000-0002-3297-9060, ${ }^{2}$ romanpanteevmail@gmail.com ORCID 0000-0003-4707-4608, ${ }^{3}$ akik_iids@ukr.net
\end{abstract}

\begin{abstract}
The paper deals with methods and algorithms for increasing the accuracy of unmanned aerial vehicle identification. Accumulation of data on radiation parameters during the session of observation of an object allows to make continuous specification of the made decisions by the set moment of the end of a session of observation the reliability of its identification would be sufficient for acceptance of necessary prompt actions. If to consider a problem of identification taking into account the specified specifics, then in its structure it is necessary to allocate several stages of decision-making depending on volume available for the considered moment of observation of data, conditions of their receiving and processing by the technical means of the information-measuring system. Observation system and control of objects of a sound emission represent difficult sound engineering complexes in which work not only equipment rooms and software, the knowledge base and data, but also intellectual resources of experts are involved. Decisions of different levels in such systems are made not only automatically technical means on the basis of formal algorithms, but also operators, on the basis of the and borrowed experience. Taking into account it is necessary to consider, both bases of creation of formal algorithms of decision-making, and feature of decision-making by the expert for the purpose of clarification of conditions of ensuring the maximum reliability of identification.
\end{abstract}

Index Terms-Sound location; unmanned aerial vehicle; identification; coordinates calculation; delay time; iteration process; measurement accuracy; sound parameters.

\section{INTRODUCTION}

Sound radiation factors of various sources are used in classical approaches of aviation acoustics for calculation of detection for unmanned aerial vehicle (UAV) noise level on the area and also for the forecast of borders of audibility of detection of UAV with the propeller power plant. At the same time improvement of accuracy of the forecast requires more detailed studying of acoustic characteristics of separate components of radiation regarding influence of an operating mode and design features of power plants [1].

The propeller engine in the course of the work generates the acoustic radiation which extends to the environment via channels of suction and an exhaust and also through walls of cylinders (structural noise). In this regard, in the muffled camera the research of acoustic characteristics of Bayraktar TB2 UAV manufactured by Baykar company was executed (Fig. 1).

Division of acoustic fields of an air screw and the piston engine was carried out on the basis of the analysis of narrow-band ranges of the sound pressure levels. It was necessary that the total radiation of the piston engine is defined by radiation at frequencies, multiple to the frequency of following of flashes in engine cylinders.

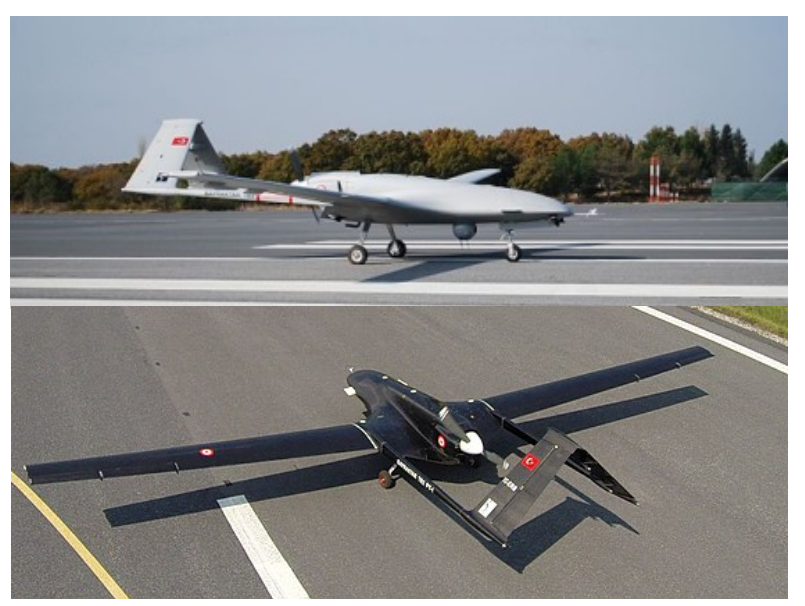

Fig. 1. UAV Bayraktar TB2 runway

The standard narrow-band range of levels of sound pressure received at measurements of acoustic characteristics of the small-sized UAV in the muffled camera is presented in Fig. 2.

For a more thorough analysis of the acoustic characteristics of the harmonics of a UAV piston 
engine, below will be given its characteristics in more narrowly targeted narrow-band range (Fig. 3)

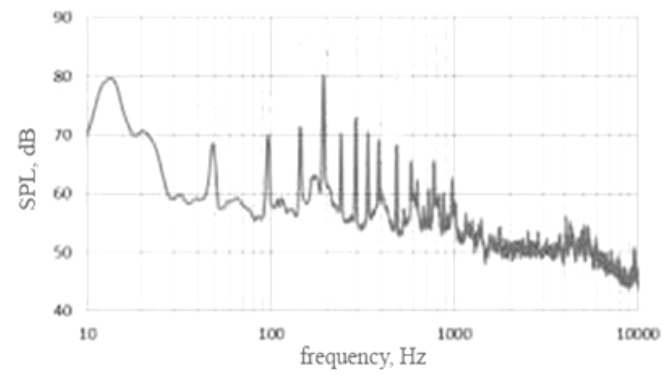

Fig. 2. Standard range of acoustic radiation of an engine of the UAV with a width bands of $2 \mathrm{~Hz}$ (rotating speed of crankshaft 5400 RPM, at distance $2 \mathrm{~m}$ )

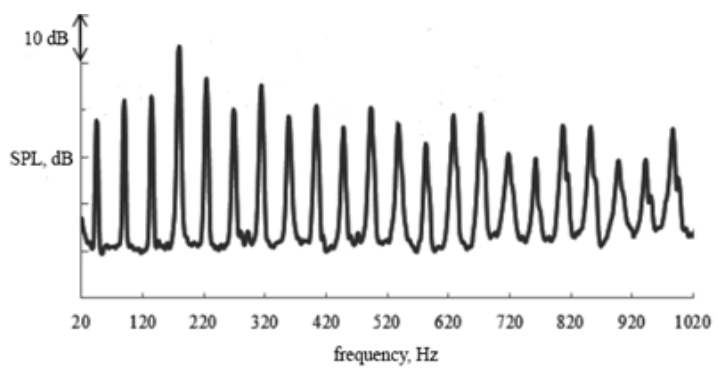

Fig. 3. Narrow-band range of the sound pressure levels in the frequency range of $20-1020 \mathrm{~Hz}$ with band width of $2 \mathrm{~Hz}$, rotating speed of the crankshaft of the engine crankshaft $=5400 \mathrm{RPM}, R=2 \mathrm{~m}$, static conditions

\section{PROBlem StATEMENT}

The dependence of acoustic power of noise of rotation of the air screw on the effective power of UAV can be received on the basis of semi-empirical model of noise of the screw according to which, the power of noise of rotation is described by formula:

$$
W=\frac{C_{1} \rho\left(\bar{r}_{e}\right)^{3}}{S_{0}^{3}}\left(\alpha^{2}+\frac{\beta^{2}}{\left(2 \pi \bar{r}_{e}\right)^{2}}\right) \frac{M_{r}^{2}}{K_{b}^{3} b_{e}} n^{6} d^{8},
$$

where $n$ are screw turns; $\alpha, \beta$ are coefficients of draft and power of the screw; $d, K_{b}, \bar{r}_{e}, b_{e}$ is the diameter of the screw, number of blades, relative radius of effective section blades and a chord of the blade in the effective section; $M_{r}$ is the Mach number of circle speed; $\rho$ is the air density; $S_{0}$ is the acoustic speed; $C_{1}$ is the coefficient proportionality; $M_{\text {rel }}$ is the Mach number e of relative flow rate in the trailer section of the blade of the screw.

The electric motor in the course of the work is capable to generate acoustic radiations, less audible the systems of passive sound monitoring, because of small quantity of mobile parts. In this regard, acoustic radiations of Bayraktar TB2 are investigated. Acoustic measurements for the quad copter were taken in the rise modes over the acoustic antenna, barraging at the height of $50 \mathrm{~m}$ and the subsequent landing. In Figure $4 \mathrm{a}$ temporary realization of record of a sound signal of the quad copter lasting $20 \mathrm{~ms}$ at a barraging stage, and in Fig. $4 \mathrm{~b}$ - rated auto correlated function (ACF) for this realization are shown [2].

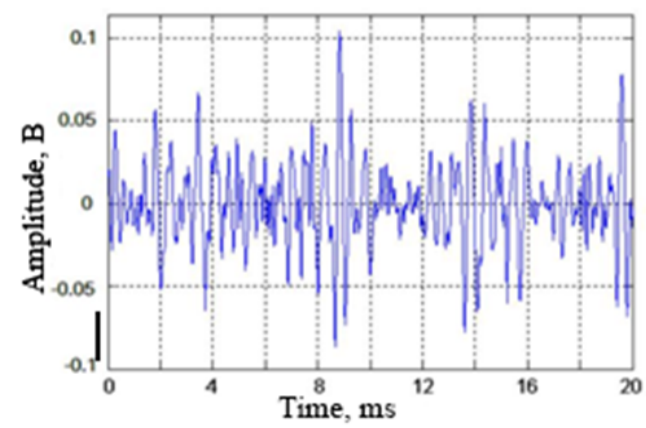

(a)

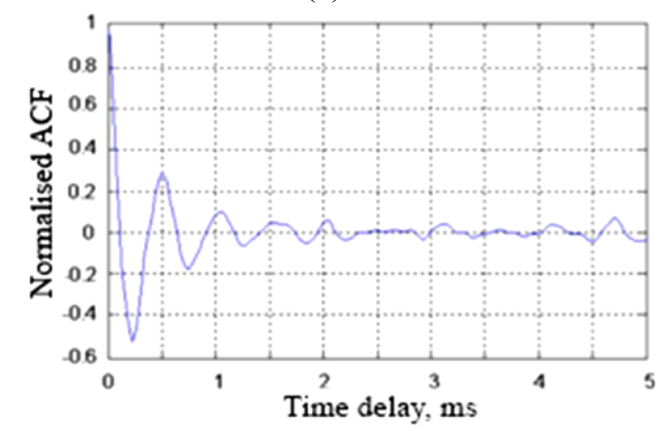

(b)

Fig. 4. Temporary realization of record of a sound signal of the quad-copter lasting $20 \mathrm{~ms}$ at a barraging stage (a) with the ACF processing (b)

\section{TECHNICAL MEANS OF THE SOUND DETECTION}

Proceeding from shortcomings of the sound monitoring systems allocated above and also the speed, appropriate to the problem solution of definition, and the UAV direction the way of integration of a system of sound monitoring and a Doppler system, in its passive variant is offered (Fig. 5).

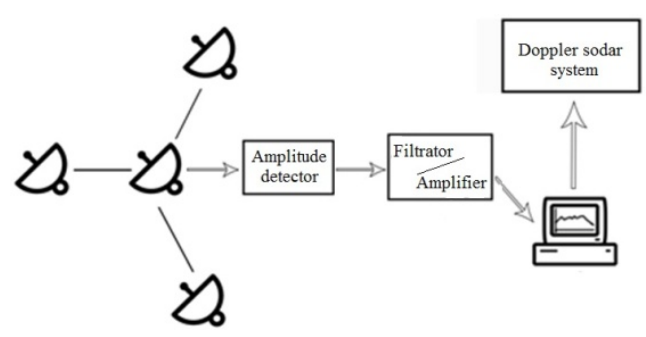

Fig. 5. General structure of the offered system of sound monitoring

The basis of the proposed method is the peculiarities of the principle of operation of Doppler systems, namely, their involvement mainly in active 
sound monitoring systems, which in turn may adversely affect the secrecy of the whole system. In Figure 5, the antenna installation of a passive system of sound monitoring is presented, which is generally including four parabolic antennas proceeding from bases of determination of coordinates of location of the UAV by the time difference of signal arrival.

Three types of directional microphones are commonly used: parabolic (reflex), tubular (interference) and flat microphone arrays.

The directional pattern of the microphone is $10^{\circ}$, the gain is $70 \mathrm{~dB}$, which provides interception of conversation in the open air at low noise levels up to $100 \mathrm{~m}$. The frequency range of the microphone is from 100 to $14,000 \mathrm{~Hz}$. The quality of the directed microphone is estimated by prize coefficient in the relation "signal hindrance" due to spatial selection $K_{n m}, \mathrm{~dB}$.

For the parabolic microphone $K_{p m}$ given coefficient, the $\mathrm{dB}$, is calculated by a formula:

$$
K_{p m} \square 10 \cdot \lg \left(1.2 \cdot 10^{-4} \cdot S_{\text {refl }} \cdot f^{2}\right),
$$

where $S_{\text {refl }}$ is the square of the reflector of the microphone, sq.m; $f$ is the signal frequency, Hz.

Apparently from a formula (2), the more the area of the reflector, the more is value of coefficient $K_{p m}$.

"Running wave" microphones (interference), often called tubular microphones [3], consist of a tube with holes or cutouts, on the back of which is a non-directional or unidirectional body of the diaphragm.

For the tubular microphone prize coefficient in the relation "signal hindrance" due to spatial selection $K_{t m}, \mathrm{~dB}$, is calculated by the formula:

$$
K_{p m} \square 10 \cdot \lg \left(6.1 \cdot 10^{-3} \cdot I \cdot f\right),
$$

where $I$ is the length of a tube, $\mathrm{m}$.

The extraordinary maximum range of tubular microphones is slightly smaller than the parabolic one. But in the city, their capabilities are almost the same.

\section{UAV IDENTIFICATION}

It is the most expedient to allocate the following stages in elaboration of the final decision of identification.

1. Detection of a sound emission in frequency band of observation and its reference to some frequency range of preprocessing of signals information carriers about object radiation parameters.

2. Estimation of power characteristics of observed intelligence signals and making decisions on achievement of sufficient level a signal noise for execution of measurement of parameters of a sound emission.

3. Estimation of the interference level and making decisions on application of additional measures of increase in noise immunity of the informationmeasuring system (IMS) measuring channels.

4. Estimation of values of informative parameters of a sound emission, accumulation of the arriving data on results of estimation and making decisions on accessory of true values of parameters to the ranges of values allowing to make identification of objects on set of all measured parameters with sufficient degree of reliability.

5. The complex analysis of the received results of measurement of informative parameters of radiation and making decisions on belonging of an observed object to the set class, to type, a sample, etc.

Observation system and control of objects of a sound emission represent difficult sound engineering complexes in which work not only equipment rooms and software, the knowledge base and data, but also intellectual resources of experts are involved.

Decisions of different levels in such systems are made not only automatically technical means on the basis of formal algorithms, but also operators, on the basis of the and borrowed experience. Taking into account it is necessary to consider, both bases of creation of formal algorithms of decision-making, and feature of decision-making by the expert for the purpose of clarification of conditions of ensuring the maximum reliability of identification.

The first of the listed above direction finding problems - detection of a sound emission in frequency band of sound observation is solved the multiple response receiver containing the same channels, each of which provides energy liberation of a sound emission in the frequency band $\Delta f_{i}$, $(i=1,2, \ldots, m)$ and comparison with some threshold value $E_{i}$ (Fig. 7).

Is a part of a $m$-channel sink frequency channels, each of which includes A1 - the device of selection of informative signs of a signal, A2 - the decision circuit.

As in the systems of a passive sound-location it is impossible to use information on a phase of the coming signal, and information on frequency can be used only at the level of distribution of all range of observation to sub ranges (bands), $\Delta F=\sum_{i=1}^{m} \Delta f_{i}$, the structure of each frequency channel is implemented on the basis of strip filtering (Fig. 8).

Indicators of reliability of radiation detection, as a rule, decide by digital single-response receivers from conditions of reception of a signal on an additive noise in the form of a Gaussian noise. 
Distribution bending around a noise output of the narrowband filter submits to Rayleigh's law:

$$
\omega\left(U_{n}\right)=\frac{U_{n}}{\sigma_{n}} \exp \left(-\frac{U_{n}^{2}}{2 \sigma_{n}^{2}}\right),
$$

where $U_{n}$ and $\sigma_{n}$ is the instant and mean square value of noise at the output of the strip filter.

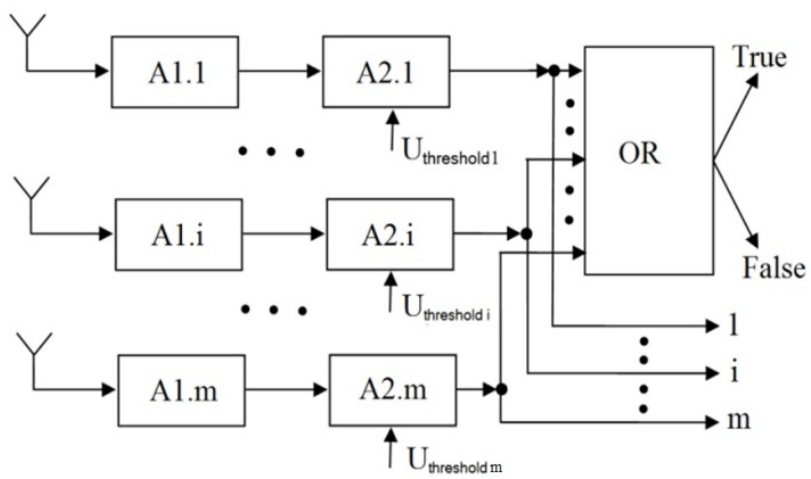

Fig. 7. Structure of the multichannel receiver for detection of a sound emission in frequency band

If to designate a threshold of decision-making through $\beta$, that probability of false alarm $P_{f a}$ can be found by a formula

$$
P_{f a}=\int_{\beta}^{\infty} \frac{U_{n}}{\sigma_{n}} \exp \left(-\frac{U_{n}^{2}}{2 \sigma_{n}^{2}}\right) d U_{n} .
$$

When the receiver is influenced by both a signal, and noise, distribution bending around the resulting distribution at the output of the filter submits to the generalized Rayleigh's law

$$
\begin{array}{r}
\omega\left(U_{s+n}\right)=\frac{U_{s+n}}{\sigma_{n}^{2}} \exp \left(-\frac{U_{s+n}^{2}+U_{s}^{2}}{2 \sigma_{n}^{2}}\right) \\
\cdot I_{0}\left(\frac{U_{s} U_{s+n}}{\sigma_{n}^{2}}\right),
\end{array}
$$

where $U_{s}$ is the maximum signal amplitude at the output of the filter which is considered the known value determined through the least square mean of noises $\sigma_{n}$ and admissible ratio signal noise $q_{0}=U_{s} / \sigma_{n} ; I_{0}$ is the Bessel's function zero order here imaginary to an argument.

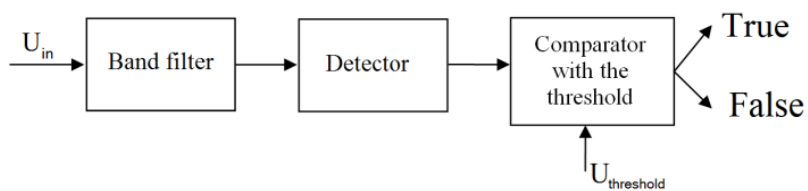

Fig. 8. Structure of the filter single-response receiver for detection of a sound emission in frequency band $\Delta f_{i}$
Taking into account the entered ratios, the probability of the correct detection can be determined by a formula:

$$
\begin{aligned}
P_{c d} & =\int_{\beta}^{\infty} \omega\left(U_{s+n}\right) d U_{s+n} \\
& =\int_{\beta}^{\infty} \frac{U_{s+n}}{q_{0}} \exp \left(-\frac{U_{s+n}^{2}+q_{0}^{2}}{2 q_{0}}\right) I_{0}\left(U_{s+n}\right) d U_{s+n} .
\end{aligned}
$$

Formulas (5) - (7) can be integrated, considering a ratio a signal noise. For accepted $P_{f a} \leq 0.1$ and $P_{c d} \geq 0.9$ this dependence can be presented in the simplified form

$$
q_{0}=2\left(\sqrt{\ln \frac{1}{P_{f a}}}+\sqrt{\ln \frac{1}{1+P_{f a}}-1.4}\right)^{2} .
$$

At an invariable threshold of decision-making, the requirement for indicators $P_{c d}$ and $P_{f a}$ differently affect necessary value a signal noise. So at $P_{c d}=0.99$ and $P_{f a}=10^{-5}$, necessary value $q_{0}=53.6$, if $P_{f a}=0.9$ and $P_{c d}=0.1$, then values of a ratio a signal noise should be $q_{0}=12.2$.

As signals of sound station in most cases have pulse character, a possible measure of improvement of reliability is their accumulation. But accumulation is possible only after nonlinear processing of signals the detector bending around as in an initial look these signals have a random initial phase. On the other hand, nonlinear processing worsens a ratio a signal noise after the detector of bending around. If characteristic of the detector is approximated by a square parabola of a look $U_{\text {out }}=a U_{\text {in }}^{2}$, and the ratio a signal noise on its entrance is equal $U_{s} / \sigma_{n}=\sqrt{q_{0}}$, then at its end the relation a signal noise will be equal

$$
\frac{U_{\text {out.s }}}{U_{\text {out. } n}}=\frac{U_{s}^{2}}{2 U_{s} \sigma_{n}+\sigma_{n}^{2}} .
$$

Follows from the given formula that at a bigger ratio a signal noise on an entrance, that is $q_{0} \succ \succ 1$ and $U_{s} \succ \succ \sigma_{n}$, at the end we have

$$
\frac{U_{\text {out.s }}}{U_{\text {out. } . n}} \approx \frac{U_{s}}{2 \sigma_{n}} \succ \succ 1,
$$

If $q_{0} \prec \prec 1$ and $U_{s} \prec \prec \sigma_{n}$, then the output ratio a signal noise is much less than unit

$$
\frac{U_{\text {out.s }}}{U_{\text {out.n }}} \approx\left(\frac{U_{s}}{\sigma_{n}}\right) \prec \prec 1 .
$$


Follows from the given ratios: in the first case the detector worsens a ratio approximately twice; in the second case deterioration can be hundreds thousands of times.

If detection is conducted on a pack from $N_{S}$ signals and requires achievement of necessary reliability of recognition to provide a ratio on its entrance $q_{0 \Sigma}$, then with the accounting of coefficient $\alpha_{\text {det }}$ losses in the detector the relation has to make a signal noise of a single signal

$$
q_{01}=\frac{q_{0 \Sigma}}{N_{c}} \alpha_{\text {det }} .
$$

Follows from the given results of the analysis of indicators of reliability of detection of a sound emission by one channel of the receiver that the crucial importance renders an initial ratio on reliability a signal - a filter input noise. Deterioration in the specified ratio many times over can worsen a ratio on a decision-making device input. At small ratios a signal - a carrier-to-receiver noise the attempt to improve it on an input of the decision making device due to accumulation can be inefficient. Considering also that in the absence of the prior information on parameters of the found signal problem definition of creation of the optimum filtering scheme is incorrect, it is necessary to state very essential limitation of set of means of increase in reliability at insufficient values of a ratio a signal noise.

Considered above extends to a case when the found signal has stable amplitude, for example, when between a radiation source and the receiving antenna direct visibility, is absent multi beam distribution of waves and an object is not mobile. In reality these conditions are not satisfied and amplitude of the coming signal changes in a random way. As show the researches, conducted in [4] the structure of the receiver and its algorithm remain the same, however, for achievement of the same indicators of reliability $P_{f a}$ and $P_{c d}$ the bigger value of average size of a ratio a signal noise on its entrance is required

$$
q_{0 a v}=2\left(\frac{\lg 1 / P_{f a}}{\lg 1 / P_{c d}}-1\right) .
$$

The dependence (13) can be used for creation of performances of the receiver. Their analysis indicates significant influence of ignorance of amplitude on indicators of reliability of detection. In particular, in that area of characteristics, where $P_{c d}$ is big, and $P_{f a}$ is small, ignorance of amplitude leads to significant increase (in hundreds of times) required value a signal noise. In the field of small values $P_{c d}$ random changes of amplitude (its emissions) can facilitate detection, on the contrary.

For estimation of indicators of reliability of detection of the multiple response receiver constructed on the basis of use of identical channels it is necessary to find dependence of probabilistic characteristics of all system on probabilities $P_{c d . i}$ and $P_{f a . i} \quad(i=1,2, \ldots, m)$ separate $i$ th channel. Owing to identity of schemes of processing and independence of the noise of probability of the correct detection and probability of false alarm operating in them in various channels it is possible to consider identical $P_{f a . i}=P_{f a . j}$ and $P_{c d . i}=P_{c d . j}$ at $i \neq j$. Probability of false detection of a signal is connected by a system with the probability of false detection by certain canals a ratio $P_{f a}=1-\left(1-P_{f a . i}\right)^{m}$. At $P_{f a . i} \prec \prec 1$ in a binomial row $P_{f a}$ it is possible it will be limited to the first two components, then

$$
P_{f a}=m P_{f a . i} .
$$

The formula (11) shows that the probability of false alarm in $m$-to a channel system in $m$ times more probabilities of false alarm in the separate scheme of processing.

Admission probability $P_{a p}$ signal the multichannel receiver it is equal to the work of probabilities $P_{a p . i}$ the admission in the relevant channel on probability $\left[\left(1-P_{f a . i}\right)^{m-1}\right]$ not excesses by the noise tension of a threshold in all other schemes is also expressed $P_{a p}=P_{a p . i}\left[\left(1-P_{f a . i}\right)^{m-1}\right]$. For case when $\left[(m-1) P_{f a . i}\right] \prec \prec 1$, the second factor can be accepted equal 1, and, in view of that the probability of the admission and the correct detection unambiguously define each other $P_{a p}=1-P_{c d}$ and $P_{a p . i}=1-P_{c d . i}$, we get

$$
1-P_{c d} \approx 1-P_{c d . i}, \text { or } P_{c d} \approx P_{c d . i},
$$

so the probability of the correct detection from identical receivers is approximately equal in a system to the probability of the correct detection by the certain canal.

Along with false detection and the admission of a signal in the multichannel receiver the distortions consisting that in the presence - a signal the threshold will be exceeded in $j$ th to the scheme can take place and it seems that there is $j$ th a signal. 
Distortion probabilities $P_{d}$ and correct instruction $P_{\text {cor }}$ unambiguously define each other $P_{f}=1-P_{\text {cor }}$.

Having carried out similar reasoning, we will find that the probability of the correct instruction is equal $P_{c o r}=P_{c d . i} \cdot\left(1-P_{f a . i}\right)^{m-1}$. Considering that for $m \succ \succ 1, \quad\left(1-P_{f a . i}\right)^{m-1} \approx 1-m \cdot P_{f a . i}, \quad$ we receive distortion probability $P_{f}=1-P_{\text {cor }}=1-P_{c d . i}+$ $+m P_{c d . i} P_{f a . i}$, which can be expressed through probabilistic characteristics of all m-channel system, considering formulas (11) and (12):

$$
P_{f}=1-P_{c d}+P_{c d} P_{f a}
$$

Formulas (17) and (18) just allow to pass from the ratios given above (12) and (13) for performance data of one channel to performance data of the multichannel receiver. For this purpose it is necessary to make replacement in formulas (17) and (18) standing there probabilities of the correct detection and false alarm for one channel, the corresponding probabilities for - a channel system, and, having made transformations, we will receive expressions of performance data of the receiver for cases of detection of a signal with an unknown phase

$$
q_{0}=2\left(\sqrt{\ln m+\ln \frac{1}{P_{f a}}}+\sqrt{\ln \frac{1}{1-P_{c d}}+1.4}\right),
$$

and unknown phase and amplitude

$$
q_{0 a v}=2\left(\frac{\lg m+\lg 1 / P_{f a}}{\lg 1 / P_{c d}}-1\right) .
$$

Ratios (14) and (15) show that if the provision of a signal on temporary and frequency axes is in advance unknown (a case in practice), then at $m$ channel detection the necessary ratio a signal noise providing demanded increases $P_{c d}$ and $P_{f a}$, reached by the single-channel receiver. However, this increase is small as in all formulas defining value $q_{0}$, the logarithm of number of channels $m$ enters.

The second stage in the list of decisions at identification of an object is estimation of power characteristics of observed signals and making decision on sufficiency of a ratio a signal noise for performance of measurement of parameters of radiation. Estimation is conducted on the output voltage of the active channel of the receiver. An ultimate goal of estimation is finding of average value of output voltage of the detector bending around. For making decision on the current ratio the signal noise needs to be found also mean square value of a deviation of output voltage. As at identification of objects by method of a passive sound location of prior data on an observed signal is not present (unlike an active location), the optimum receiver in the systems of a passive location calculates the relation of credibility or the moment of function of credibility.

\section{CONCLUSIONS}

The problem of UAV identification with means of the passive sound location belongs to dynamic, decided in continuously changing conditions that is defined by several factors connected with features as the identified objects, and the systems of a location carried to the category of specialized informationmeasuring system (IMS):

- change of conditions of reception of the signals arriving from objects at their movement in relation to reception antennas of the locational station, maneuvering of an object, change of characteristics and parameters of the radiation formed by it including hindrances;

- change of properties of receiving channels of sound station in the conditions of continuous changes of the characteristics arriving on the entrances of signals caused first of all overloads and action of hindrances;

- limited time of stay of an object in an observation zone;

- requirement of timeliness, relevance and maximum completeness of information available to receiving at every moment of observation of an object.

Accumulation of data on radiation parameters during the session of observation of an object allows to make continuous specification of the made decisions by the set moment of the end of a session of observation the reliability of its identification would be sufficient for acceptance of necessary prompt actions. If to consider a problem of identification taking into account the specified specifics, then in its structure it is necessary to allocate several stages of decision-making depending on volume available for the considered moment of observation of data, conditions of their receiving and processing by the IMS technical means.

\section{REFERENCES}

[1] R. Giladi, "Real-time identification of aircraft sound events, Elsevier," Transportation Research, Part D: Transport and Environment, vol. 87, 2020. https://doi.org/10.1016/j.trd.2020.102527

[2] S. Nihtianov and A. Luque, Smart sensors and MEMS, Woodhead Publishing, ISBN 978-0-08- 
102055-5, p. $\quad 604, \quad 2018$. https://doi.org/10.1016/C2016-0-01622-4

[3] M. Tarabini and G. Moschioni, "Unattended acoustic events classification at the vicinity of airports," Elsevier, Applied Acoustics, vol. 84, 2014. https://doi.org/10.1016/j.apacoust.2014.03.013
[4] M. Genescà and J. Romeu, "Measurement of aircraft noise in a high background noise environment using a microphone array," Elsevier, Transportation Research, Part D: Transport and Environment, vol. 18, pp. 70-77, 2013. https://doi.org/10.1016/j.trd.2012.09.002

Received November 16, 2020.

Sineglazov Victor. orcid.org/0000-0002-3297-9060

Doctor of Engineering Science. Professor. Head of the Department.

Aviation Computer-Integrated Complexes Department, Faculty of Air Navigation Electronics and Telecommunications, National Aviation University, Kyiv, Ukraine.

Education: Kyiv Polytechnic Institute, Kyiv, Ukraine, (1973).

Research area: Air Navigation, Air Traffic Control, Identification of Complex Systems, Wind/Solar power plant.

Publications: more than 660 papers.

E-mail:svm@nau.edu.ua

Pantyeyev Roman. Candidate of Engineering Science. Senior Teacher.

Aviation Computer-Integrated Complexes Department, Faculty of Air Navigation, Electronics and Telecommunications, National Aviation University, Kyiv, Ukraine.

Education: Donetsk National Technical University, Donetsk, Ukraine, (2001).

Research area: Information Systems, Control Systems Design, Identification of Complex Systems, Mathematical Modeling.

Publications: more than 20 scientific papers.

E-mail: romanpanteevmail@gmail.com

Balov Oleksandr. Master of Science.

Aviation Computer-Integrated Complexes Department, Faculty of Air Navigation, Electronics and Telecommunications, National Aviation University, Kyiv, Ukraine.

Education: National Aviation University, Kyiv, Ukraine, (2020).

Research area: Control Systems Design, Mathematical Modeling.

Publications: 1.

E-mail: romanpanteevmail@gmail.com

В. М. Синєглазов, Р. Л. Пантєєв, О. В. Балов. Автоматична система ідентифікації БПЛА багатопозиційними засобами звукового моніторингу

У статті розглядаються методи і алгоритми підвищення точності ідентифікації безпілотного літального апарату за допомогою багатопозиційного комплексу звукового моніторингу. Накопичення даних про параметри випромінювання під час періоду спостереження за об'єктом дозволяє здійснювати безперервне уточнення прийнятих рішень до заданого моменту закінчення процесу спостереження, достовірність ідентифікації при цьому буде достатньою для прийняття необхідних оперативних дій. При розгляді задачі ідентифікації 3 урахуванням зазначеної специфіки розглядається кілька етапів прийняття рішення в залежності від обсягу наявних даних на момент спостереження, умов їх отримання і обробки інформаційно-вимірювальними системами. Системи ідентифікації об'єктів звукового випромінювання являють собою складні технічні комплекси, в роботі яких задіяні не тільки апаратне та програмне забезпечення, база знань і безпосередньо дані, але також і інтелектуальні ресурси фахівців. Рішення різного рівня в таких системах приймаються не тільки автоматично технічними засобами на основі формальних алгоритмів, але i операторами, на основі накопиченого і запозиченого досвіду. При розробці таких систем необхідно враховувати як основи побудови формальних алгоритмів прийняття рішень, так і особливості прийняття рішення експертом 3 метою визначення умов для забезпечення максимальної надійності ідентифікації.

Ключові слова: звуковий моніторинг; безпілотний літальний апарат; ідентифікація; обчислення координат; час затримки; ітераційний процес; точність вимірювання; параметри звуку.

Синєглазов Віктор Михайлович. orcid.org/0000-0002-3297-9060.

Доктор технічних наук. Професор. Завідувач кафедрою.

Кафедра авіаційних комп'ютерно-інтегрованих комплексів, Факультет аеронавігації електроніки i телекомунікацій, Національний авіаційний університет, Київ, Україна.

Освіта: Київський політехнічний інститут, Київ, Україна, (1973).

Напрям наукової діяльності: аеронавігація, управління повітряним рухом, ідентифікація складних систем, вітроенергетичні установки.

Кількість публікацій: більше 660 наукових робіт.

E-mail: svm@nau.edu.ua 
Пантсєв Роман Леонідович. Кандидат технічних наук. Старший викладач.

Кафедра авіаційних комп'ютерно-інтегрованих комплексів, Факультет аеронавігації, електроніки та телекомунікацій, Національний авіаційний університет, Київ, Україна.

Освіта: Донецький національний технічний університет, Донецьк, Україна, (2001).

Напрямок наукової діяльності: інформаційні системи, проектування систем управління, ідентифікація складних систем, математичне моделювання.

Публікації: понад 20 наукових робіт.

E-mail: romanpanteevmail@gmail.com

Балов Олександр Володимирович. Магістр.

Кафедра авіаційних комп'ютерно-інтегрованих комплексів, Факультет аеронавігації, електроніки та телекомунікацій, Національний авіаційний університет, Київ, Україна.

Освіта: Національний авіаційний університет, Київ, Україна, (2020).

Напрямок наукової діяльності: проектування систем керування, математичне моделювання.

Публікації: 1.

E-mail: romanpanteevmail@gmail.com

В. М. Синеглазов, Р. Л. Пантеев, А. В. Балов. Автоматическая система идентификации БПЛА многопозиционными средствами звукового мониторинга

В статье рассматриваются методы и алгоритмы повышения точности идентификации беспилотного летательного аппарата при помощи многопозиционного комплекса звукового мониторинга. Накопление данных о параметрах излучения во время периода наблюдения за объектом позволяет осуществлять непрерывное уточнение принятых решений к заданному моменту окончания процесса наблюдения, достоверность идентификации при этом будет достаточной для принятия необходимых оперативных действий. При рассмотрении задачи идентификации с учетом указанной специфики рассматривается несколько этапов принятия решения в зависимости от объема имеющихся на рассматриваемый момент наблюдения данных, условий их получения и обработки информационно-измерительными системами. Системы идентификации объектов звукового излучения представляют собой сложные технические комплексы, в работе которых задействованы не только аппаратное и программное обеспечение, база знаний и непосредственно данные, но также и интеллектуальные ресурсы специалистов. Решения разного уровня в таких системах принимаются не только автоматически техническими средствами на основе формальных алгоритмов, но и операторами, на основе накопленного и заимствованного опыта. При разработке таких систем необходимо учитывать как основы построения формальных алгоритмов принятия решений, так и особенности принятия решения экспертом с целью определения условий для обеспечения максимальной надежности идентификации.

Ключевые слова: звуковой мониторинг; беспилотный летательный аппарат; идентификация; вычисление координат; время задержки; итерационный процесс; точность измерения; параметры звука.

Синеглазов Виктор Михайлович. orcid.org/0000-0002-3297-9060

Доктор технических наук. Профессор. Заведующий кафедрой.

Кафедра авиационных компьютерно-интегрированных комплексов, Факультет аэронавигации электроники и телекоммуникаций, Национальный авиационный университет, Киев, Украина.

Образование: Киевский политехнический институт, Киев, Украина, (1973).

Направление научной деятельности: аэронавигация, управление воздушным движением, идентификация сложных систем, ветроэнергетические установки.

Количество публикаций: более 660 научных работ.

E-mail:svm@nau.edu.ua

Пантеев Роман Леонидович. Кандидат технических наук. Старший преподаватель.

Кафедра авиационных компьютерно-интегрированных комплексов, Факультет аэронавигации, электроники и телекоммуникаций, Национальный авиационный университет, Киев, Украина.

Образование: Донецкий национальный технический университет, Донецк, Украина, (2001).

Направление научной деятельности: информационные системы, проектирование систем управления, идентификация сложных систем, математическое моделирование.

Публикации: более 20 научных работ.

E-mail: romanpanteevmail@gmail.com

Балов Александр Владимирович. Магистр.

Кафедра авиационных компьютерно-интегрированных комплексов, Факультет аэронавигации, электроники и телекоммуникаций, Национальный авиационный университет, Киев, Украина.

Образование: Национальный авиационный университет, Киев, Украина, (2020).

Направление научной деятельности: проектирование систем управления, математическое моделирование.

Публикации: 1.

E-mail: romanpanteevmail@gmail.com 